\title{
Democracia para a superação do capital no pensamento marxista: subsídios para reflexões sobre a organização educacional
}

\author{
Angela Maria Hidalgo*
}

\section{Resumo}

Este artigo apresenta pesquisa bibliográfica motivada pelos debates em torno da questáo da participaçáo nos processos decisórios no contexto das reformas política e educacionais dos anos de 1990. Defende-se a tese de que a democracia constitui premissa básica para a transformação social, demonstrada na análise do pensamento de autores marxistas. O estudo indica: em Marx e Engels, a análise do desenvolvimento histórico do processo de planificação coletiva da produção e a necessária manutenção dos níveis de produtividade para a criação das condiçóes de superação do capitalismo; em Luxemburgo e Lênin, divergências quanto ao processo de transição ao socialismo; em Luxemburgo, a defesa da participação das massas no processo decisório. A conclusão é a de que a abordagem dos aspectos políticos das questóes organizativas, concomitante à garantia de acesso ao conhecimento produzido historicamente, requer avanços na análise dos princípios organizacionais na educação com base nas especificidades desta prática social.

Palavras-chave: Democracia. Gestão educacional. Marxismo. Educação.

* Doutora em Educação pela Unesp - Marília. Professora Adjunta do Departamento de Pedagogia da Universidade Estadual do Centro-Oeste, PR. 


\section{Introdução}

No momento histórico atual de crise do modo de produção capitalista em que ocorrem processos de transformação tanto nos âmbitos da estruturação da produção, quanto nos princípios políticos de organização e intervenção do Estado, com profundo impacto sobre a educação, são implementadas, a partir da década de 1990, reformas educativas que apresentam como eixo central a descentralização administrativa e a gestão democrática. Nesse contexto, a questão da participação política assume matizes diferenciados.

Podemos indicar nesse processo de mudanças a existência de tendências funcionalistas que concebem a sociedade como um todo orgânico, sem contradiçôes, em que as chamadas disfunçóes são entendidas como de ordem individual e a participação pensada como amálgama social. Indicamos também concepçóes que, não obstante reconheçam a existência das desigualdades sociais, pensam a participação como um instrumento para conquistas sociais gradativas a fim de minimizar as mazelas socioeconômicas pela via da humanização do capitalismo. Essas vertentes estão, portanto, muito próximas de perspectivas para as quais a superação dos problemas socioeconômicos e políticos podem ocorrer por meio de pequenas mudanças nos comportamentos individuais e dos pequenos grupos, no âmbito da cultura, abandonando a perspectiva da necessidade de uma ruptura da ordem econômica. Essa perspectiva, presente em autores identificados com o pensamento pós-moderno e com a chamada Terceira Via como padrão de intervenção social, consideram as análises macroeconômicas como metanarrativas, portanto autoritárias e impositivas, por serem pensadas por grupos de intelectuais supostamente vanguardistas que conduziriam uma massa popular passiva. Estas análises associam o pensamento marxista ao autoritarismo, tomando como referência apenas as experiências históricas dos países socialistas; reduzindo a contribuição da perspectiva marxista ao "leninismo" consideram que a implementação dos princípios veiculados por estes autores desembocaria no totalitarismo.

Pretendemos neste artigo demonstrar a importância da democratização das relaçóes sociais no pensamento de dois autores clássicos do marxismo, Lênin e Rosa Luxemburg, como ponto de partida para pensar os processos de participação social sob uma perspectiva de classe, cujos horizontes implicam 
a superação do modo de produção capitalista. Na produção destes autores encontra-se a premissa de que as possibilidades históricas de superação do capitalismo dependem, além das condições materiais e científicas de produção social da subsistência humana, das condições políticas de constituição do Estado e da intervenção de sujeitos com autonomia moral e intelectual, engajados socialmente na reconstruçáo permanente dos espaços coletivos, o que, por sua vez, implica no exercício da democracia, ${ }^{1}$ ainda sob a égide do capitalismo.

A análise baseada no materialismo histórico-dialético de Marx e Engels mostra que o movimento de transformação do capitalismo sofre uma pressão permanente das forças produtivas para a superação de seu caráter de capital privado em direção ao reconhecimento de sua dimensão social. Historicamente, o sistema capitalista desenvolve um processo gradativo de planificação da produção dentro de limites que permitem a manutenção de suas características essenciais. Primeiramente, organizaram-se as sociedades anônimas e os trustes (destinados a regular a produção, mas que acabaram por intensificar a concentração de capital), até a assunção da planificação da produção pelo Estado capitalista.

Nos trustes, a livre concorrência transforma-se em monopólio e a produção sem plano da sociedade capitalista capitula ante a produção planificada e organizada da nascente sociedade socialista. É claro que no momento em proveito e benefício dos capitalistas. Mas aqui a exploração torna-se tão patente, que tem forçosamente que ser derrubada. (ENGELS, 1987, p. 329).

Como "representante oficial da sociedade capitalista", o Estado tornase o "capitalista coletivo ideal" e assume a propriedade das forças produtivas que "não é a solução do conflito, mas abriga já em seu seio o meio formal, o instrumento para chegar à solução", uma vez que o passo necessário para o reconhecimento do caráter social dos meios de produção está dado (ENGELS, 1987, p. 330-331).

O Estado, como capitalista coletivo ideal, não oferece, de fato, todas as condições necessárias para a constituição do modo socialista de produção. Os balanços da estrutura produtiva das sociedades pós-capitalistas soviéticas 
mostraram que estas permaneceram em um caráter transitório, mesmo tendo transferido a apropriação dos meios de produção dos produtores individuais para a estrutura burocrática do Estado. Independentemente de ser o Estado ou serem os produtores individuais que detêm o controle sobre a estrutura produtiva, mantém-se o capital como elemento de subjugação do trabalho.

Em Lênin, o Estado, como produto dos interesses antagônicos entre as classes sociais, deve ser extinto para a construção da sociedade socialista. Como o Estado só existe em função da presença "do caráter inconciliável das contradiçôes de classe", ele surge e desenvolve-se como "órgão de dominação de classe, um órgão de opressão de uma classe por outra”, cumprindo o papel de moderação do conflito entre as classes (LÊNINE, 1978, p. 15). Portanto, com a abolição da propriedade privada dos meios de produção, o horizonte do marxismo-leninismo prevê a supressão da estrutura do Estado burguês.

Para Engels (1987), ao lado de condições materiais que favoreçam a transformação do capitalismo em socialismo destaca-se a ação do proletariado. Para que esta ação seja efetiva o proletariado deve primeiramente reconhecer as características estruturais do sistema, de sua dinâmica de reprodução e expansão, assim como das condições favoráveis à sua intervenção. $\mathrm{O}$ pensador alemão salienta que, enquanto não conhecemos as forças da sociedade, estas atuam como as forças da natureza (cega e violentamente). "Mas, uma vez conhecidas, logo que se saiba compreender sua ação, suas tendências e seus efeitos, está em nossas mãos o sujeitá-las cada vez mais à nossa vontade e, por meio delas, alcançar os fins propostos" (ENGELS, 1987, p. 331).

A identificação das condições materiais de superação do capitalismo remete a uma questão estrutural a ser observada nos contextos históricos específicos. Marx e Engels indicam, já a partir da análise das contradiçóes essenciais do sistema capitalista, que a superação da existência das classes sociais, calcada na divisão do trabalho, implica na eliminação da apropriação privada dos meios de produção e dos produtos, da cultura e na condução espiritual da sociedade por um dos segmentos sociais; exige, portanto, o reconhecimento e concretização do caráter social dos meios de produção e, consequentemente, a apropriação do controle por parte dos "produtores associados" desta mesma produção.

Outro aspecto a ser observado neste quadro teórico acerca das condições materiais para a superação do modo de produção capitalista 
diz respeito aos níveis de produtividade material para a satisfação das necessidades sociais. Para Engels, a divisão entre classes sociais não deixará de existir a partir somente da consciência de que ela é inadmissível do ponto de vista da justiça. Enquanto o montante de trabalho desempenhado pela sociedade for suficiente apenas para as necessidades básicas, "enquanto, por isso, o trabalho absorver todo o tempo, ou quase todo o tempo, da imensa maioria dos membros da sociedade, esta se divide, necessariamente, em classes" (ENGELS, 1987, p. 333).

Assim, a superação das classes sociais demanda elevados níveis de produtividade, para além da medida das necessidades de subsistência individual, de todas as necessidades coletivas historicamente existentes ${ }^{2}$. Ou seja, sob o socialismo, os níveis de produtividade atingidos pela estrutura capitalista devem ser não apenas mantidos, mas ampliados, pois, uma vez que se retroceda a um estado de necessidade individual e coletivo, emerge a perversidade da apropriação privada. A nova sociedade proposta, portanto, pressupóe

um grande incremento da força produtiva, ou seja, um alto grau de seu desenvolvimento. [...] sem ele apenas generaliza-se a escassez e, portanto, com a carência, recomeçaria novamente a luta pelo necessário, e toda a imundície anterior seria restabelecida. (MARX; ENGELS, 1987 apud MÉSZÁROS, 2002, p. 614).

Voltemos a uma questão central na discussão da transição, o problema da necessidade, qualidade e uso. Sob o regime capitalista, rompe-se o vínculo entre produção e uso, ou seja, a produção voltada para a satisfação das necessidades humanas. Como nesse regime a produção orienta-se fundamentalmente para a efetivação do valor da mercadoria, a atual dinâmica sociometabólica do sistema promove a restrição do número de consumidores com a redução do nível de utilização das mercadorias. Isto ocorre em função de que uma generalização do consumo demandaria alteraçóes profundas no modo de distribuição do produto social e traria riscos de descaracterização do capitalismo pela introdução de necessárias alteraçóes no modo de apropriação do produto social. Desse modo, a nova dinâmica sociometabólica opera a ampliação da produção e da efetivação do valor das mercadorias, promovendo a criação de produtos descartáveis 
com alto valor agregado e a ampliação da produção voltada para o complexo industrial-militar: a energia produtiva é voltada para o consumo destrutivo. Consequentemente, os critérios que devem orientar as relaçóes entre necessidade, qualidade e uso na sociedade socialista não se referem apenas à "satisfação das exigências materiais elementares do sociometabolismo", mas aplicam-se também aos "vários esforços que visam ampliar as dimensóes mais mediadas da reprodução cultural” (MÉSZÁROS, 2002, p. 615).

Os autores marxistas analisados defendem, portanto, a construção de um regime para a satisfação das necessidades coletivas e individuais em uma dinâmica de apropriação coletiva e individual: coletiva para atender às exigências de ampliação da produção; individual para permitir, além da subsistência material, também o atendimento das necessidades subjetivas produzidas historicamente.

O regime capitalista de produção [...] será substituído pelo regime de apropriaçáo do produto que o caráter dos modernos meios de produção está reclamando: de um lado, apropriação diretamente social, como meio para manter e ampliar a produção; de outro lado, apropriaçáo diretamente individual, como meio de vida e de proveito [...] o homem sai definitivamente do reino animal e se sobrepóe às condiçóes animais de existência, para submeter-se a condiçóes de vida verdadeiramente humanas. (ENGELS, 1987, p. 331-334).

Para a construção do socialismo não basta que o controle do capital mude de mãos; é necessário que se erradique o próprio capital como elemento de controle sobre o trabalho, mediante a ação dos "produtores livremente associados", reconstituindo o "processo de trabalho de acordo com seu caráter diretamente social” (MÉSZÁROS, 2002, p. 723). A erradicação do comando do capital sobre o trabalho "é inconcebível sem superar irreversivelmente a objetivação alienada do trabalho sob todos os seus aspectos, incluindo o Estado político". A transformação constitui-se em uma "revolução social [...] dos produtores associados que deve 'subordinar todos os elementos da sociedade a ela”' (MÉSZÁROS, 2002, p. 722-726).

Outro aspecto referente ao estabelecimento de um intercâmbio socioeconômico refere-se à sua impossibilidade de encaminhar-se 
espontaneamente. Esse processo exige um conjunto de tarefas com um caráter de novidade qualitativa que, por sua vez, necessita de conhecimentos jamais legitimados pelo sistema capitalista, relacionados a alteraçóes radicais na regulação da produção e na distribuição do excedente econômico. Essas mudanças só se efetivam "pelo processo político autônomo" que representa uma "regulação política adequada" no empreendimento de uma transição para uma "ordem metabólica socialista autorreguladora” (MÉSZÁROS, 2002, p. 738).

Dois aspectos são necessários nessa transição, um negativo, relativo à expropriação dos expropriadores, e um positivo, concernente a "uma articulação bem sucedida das funçóes autônomas e positivamente reguladoras pelas quais os produtores associados podem colocar nas finalidades por eles mesmos escolhidas os frutos do seu trabalho excedente"(MÉSZÁROS, 2002, p. 738). A finalidade primeira a ser perseguida para que se viabilize a consolidação do socialismo refere-se ao controle político, por parte dos produtores associados, sobre a extração do trabalho excedente. "Este é o caso em todos os domínios e em todos os níveis do sociometabolismo" (MÉSZÁROS, 2002, p. 738).

Logo, é necessário um "modo global de controle sociometabólico nãoconflituoso", ou seja, uma coordenação das células produtivas cuja forma política tenha uma articulação institucional e práticas "não hierárquicas" (MÉSZÁROS, 2002, p. 742).

O elemento da objetivação do trabalho com um caráter emancipador atinge, por conseguinte, a esfera educativa uma vez que remete à necessidade de incorporação dos avanços tecnológicos para a manutenção dos níveis de produtividade, essenciais à construção da alternativa socialista. A indispensável manutenção dos níveis de produtividade do trabalho repensados seus princípios organizativos para a necessária superação da alienação do trabalho - tem no campo da epistemologia um conjunto de reflexóes acerca da natureza e consolidação do conhecimento que orienta tanto as práticas pedagógicas quanto as organizacionais nas escolas. Neste sentido, autores que discutem as questóes organizacionais na área educacional na perspectiva marxista (GONÇALVES, 1980; PARO, 2000; FELIX, 1989) criticam o mero transplante dos princípios da administração geral para a gestão escolar e indicam a necessidade de resgatar como especificidade da educação formal, no conjunto das práticas sociais, o acesso ao conhecimento 
sócio-histórico como atualização do ser humano genérico em cada indivíduo. Este resgate é necessário em função de que são os objetivos educacionais que orientarão a elaboração de princípios administrativos em cada situação.

Tendo em vista os horizontes da alternativa socialista, entendemos que a reversão da tendência histórica de cópia ou transplante dos modos de organização empresariais para a estruturação do sistema educacional implica não apenas em nos valermos das positividades do capitalismo para o aumento da produção, mas também em nos apropriarmos dos elementos epistemológicos para a ampliação do referencial organizativo, tanto nas escolas como na organização da produção social.

Reafirmamos a característica essencial das teorias emancipatórias contemporâneas que assumem a perspectiva filosófica marxista e que as distingue das demais: o horizonte da transformação social calcada na análise das relações de produçáo e seus reflexos na subjetividade humana tendo em vista a superação do modo de produção capitalista.

Neste início do século XXI está lançada a questão da transição, não como forma de chegar ao poder, mas de, quando no poder, como partidos socialistas, no comando de economias capitalistas, encaminhar as proposiçóes das políticas públicas como forma de construção do socialismo. Essa discussão tem permeado o movimento operário e os embates entre as diversas vertentes do marxismo, constituindo-se a Revolução Russa de outubro de 1917 um marco. Primeiro porque, pela primeira vez, concretizase a construção de uma sociedade marxista, com um movimento transpondo os limites da Europa e América do Norte, expandindo-se para o chamado Terceiro Mundo; segundo porque, a partir de então, “as versóes comunistas do marxismo foram separadas das social-democratas por incompreensão e hostilidade recíprocas" (HOBSBAWM, 1985, p. 16).

Após 1917, também as condiçóes históricas desenvolveram um grau de complexidade, como o período pós-crise mundial de 1929-1933, a emergência do Fascismo, a ascensão de governos marxistas em outros Estados, o fim dos impérios coloniais, assim como o crescimento vertiginoso da economia capitalista mundial nos anos 50 e 60 do século XX. Esta conjuntura reclamava a incorporação de novos fenômenos aos tradicionalmente tratados pelas teorias marxistas. A dificuldade de tratamento desse novo panorama residia sobretudo na "cisão" entre as vertentes social-democratas e a vertente comunista ortodoxa do marxismo. Se de um lado a social-democracia foi 
atenuando a diferença entre a "democracia liberal e a luta pelo poder da classe operária, entre o 'capitalismo organizado' e a possível transição ao socialismo [...]", por outro lado o marxismo comunista tornou-se mais rigidamente ortodoxo, a ponto de dificultar "uma modernização realista da análise marxista” (HOBSBAWM, 1985, p. 20).

Entre 1927 e 1931, do regime socialista comandado por Stalin emerge um poder totalitário, caracterizado pela imposição de um monolítico marxismo-leninismo, convertendo-se em "ideologia de Estado", que impede o tratamento das questóes políticas na forma em que foram analisadas por Marx e Engels (BORON, 2001, p. 34).

O fato de os países comunistas de inspiração marxista não terem suprimido o capital e estabelecido uma ditadura do Estado não prejudica a análise marxista das contradiçôes do sistema capitalista, mesmo porque o distanciamento histórico agora permite avaliar que a derrocada de tais regimes se deu em função de desdobramentos históricos que se caracterizaram por uma centralização de poderes e pelo estabelecimento de uma "ideologia de Estado" não prevista na análise marxista de organização do regime socialista. Ao mesmo tempo, esse distanciamento possibilita ver que as formas de reestruturação do sistema capitalista face às suas contradiçóes são nefastas para a sobrevivência da vida humana e só poderão ser superadas mediante a revisão da sua lógica estrutural dissipando, assim, qualquer dúvida sobre a premência de uma revolução política.

\section{Vertentes do marxismo e a questão democrática}

Uma organização proletária se distingue de uma organizaçáo burguesa essencialmente pelo fato de que a emancipação individual é um elemento essencial de sua estratégia de luta (NEGT, 1985).

Diferentes suposiçóes acerca das transformaçóes a serem empreendidas na sociedade capitalista em prol da construção do socialismo decorrem de uma característica presente na obra de Marx e Engels: a oscilação "entre três formas de articulação entre economia capitalista e trabalho" (CHAUÍ, 2000, p. 156). Em certas passagens, Marx escreve que "a economia capitalista cria, isto é, traz ao ser, o trabalho abstrato"; em outros textos consta que a 
economia "manifesta, isto é, faz aparecer o que sempre esteve lá, escondido: igualdade e identidade entre os homens e seus trabalhos"; e em outros textos, ainda, "a economia capitalista esconde, isto é, dá a aparência de homogeneidade ao que é essencialmente heterogêneo: os indivíduos e seus trabalhos na produção de mercadorias" (CHAUÍ, 2000, p. 156-157).

Como desdobramentos destas interpretações marxianas, Chauí (2000, p. 158) aponta as seguintes vertentes históricas: o marxismo leninista, o luxemburguismo e a social-democracia. Se o capitalismo "cria a abstração do trabalho", o socialismo será viabilizado pela revolução, a partir de uma transição; mas, se o capitalismo "manifesta a abstração do trabalho que sempre esteve lá [...] então o socialismo é [...] a negação absoluta de todo o passado da humanidade"; entretanto, se a economia capitalista "esconde a heterogeneidade e individualidades reais [...] o socialismo pode ser só uma reforma nas condições e no processo de trabalho".

$\mathrm{O}$ destaque dado pela autora a estes posicionamentos reside no fato de que tanto a social-democracia quanto o leninismo constituem-se em posicionamentos utópicos (em referência ao socialismo científico elaborado por Marx e Engels) por serem análises parciais e por privilegiarem a parte em detrimento do todo. No caso da social-democracia, por supor que alteraçóes na estrutura jurídica desencadeariam transformaçóes na base material da existência; no caso do leninismo, por pressupor que a socialização dos meios de produção e da ação do partido vanguardista revolucionário constitui-se em mecanismo de transformação da sociedade rumo ao socialismo.

Em função desses impasses, surgidos nos desdobramentos sóciohistóricos da teoria marxiana, a questão da democracia, da participação, do peso da articulação da sociedade civil sobre as decisóes do Estado, até mesmo sobre a constituição deste, estão sendo revistas atualmente nas obras de Marx e Engels a fim de repensar a transição do capitalismo para o socialismo.

$\mathrm{Na}$ "Introdução" ao texto de Marx As Lutas de Classes em França de 1848 a 1850, escrita em 1895, Engels desenvolve, segundo Boron (2001, p. 101), basicamente duas teses: a) "a transição para o socialismo concebido desde uma perspectiva de 'longa duração' e não exclusivamente de um curto prazo"; e b) "a revalorização das potencialidades abertas ao movimento trabalhista pelo voto universal e pelo novo 'peso' do estado nos capitalismos democráticos, e suas consequências sobre a estratégia das forças socialistas”. 
Sobre a premissa "a", considera-se que, ao reconhecer a capacidade do capitalismo para a superação das suas crises, Engels (1895 apud BORON, 2001) questiona a estratégia dominante no movimento operário de pregar a iminência do "combate decisivo", ou seja, a luta que começaria num tempo próximo e culminaria com a vitória do proletariado. Para ele, caso se chegue a essa instância, isto eventualmente ocorrerá no final de um longo ciclo histórico; assume-se, portanto, um horizonte temporal mais prolongado e reveem-se as formas e métodos de organizaçáo e luta adequados a tais circunstâncias. Engels (1895 apudBORON, 2001) antecipa-se a Gramsci na colocação da necessidade da elaboração da contra-hegemonia ao pensamento dominante para a construção do "novo bloco histórico". O legado clássico da teoria marxista, antes de Gramsci, era o único que tratava da transição do capitalismo para o socialismo: pregava uma transição abrupta, violenta. A revisão deste pressuposto é antecipada por Engels (1895 apud BORON, 2001, p. 107) e sistematizada por Gramsci que prevê "a culminância de um extenso ciclo histórico assinalado pela insurgência das massas oprimidas”.

Sobre a premissa "b", Engels (1895 apud BORON, 2001) aponta duas transformaçóes nos Estados burgueses: possibilidades abertas pelo voto universal (ainda restrito) e a crescente complexidade dos Estados capitalistas, com grande número de aparelhos e instituiçóes. Marx apontara as contradiçôes entre capital e democracia quando esta, sob o modo de produção capitalista, exige que os dominados avancem na emancipação política até o limite da emancipação social, permitindo que os dominadores conduzam a restauração social sem que isto signifique uma transformação política.

Engels (1895 apud BORON, 2001) valoriza o significado do voto universal; ainda na "Introdução" referida sugere que não se subestimem seus efeitos mobilizadores e sua funcionalidade em termos de projeto socialista, indicando que o voto universal torna possível, sob certas circunstâncias, uma significativa acumulação de forças nas mãos dos partidos da classe operária. $\mathrm{O}$ autor lembra, entretanto, que o sufrágio universal não implica na renúncia ao "direito da revolução" por não acreditar que "a democracia eleitoral cancele a inevitabilidade da fratura revolucionária na hora de superar o capitalismo" (BORON, 2001, p. 111).

Os socialistas deveriam preparar-se para um trabalho "longo e perseverante", encaminhando 
para conquistar a consciência dos setores populares e das camadas intermediárias da sociedade, e afiançar a gravitação das forças de esquerda no complexo entrelace das instituiçôes do Estado burguês - sistema partidário, movimento operário, governos locais etc. - até que se convertam "... na potência decisiva do país, diante da qual terão que se inclinar, queiram ou não, todas as demais potências [...]" (ENGELS, 1987 apud BORON, 2001, p. 114).

Sobressai nesse pensamento, portanto, o caráter de complementaridade entre o voto e a revolução. Com relação ao primeiro, a ampliação das vitórias eleitorais dos socialistas constitui-se condição para a revolução uma vez que demonstra a capacidade de desenvolvimento de sua hegemonia. Os processos democráticos, dentre eles o voto universal, serão um dos elementos principais do novo estado socialista, pois, além de configurar-se em uma condição indispensável para a tomada do poder, a renúncia à democracia pode favorecer a implantação de um "socialismo despótico e autoritário" que não se sustenta nem ao menos pelas suas justificativas igualitárias. Quanto à segunda, a revolução, a realização da democracia não é possível sob o modo de produção capitalista, posto que sua existência depende de uma organização econômica e social calcada na "igualdade significativa dos cidadãos", em que "desapareçam as estruturas de exploração e opressão características da sociedade burguesa", implicando "uma transição para uma sociedade pós-capitalista, o que recoloca a necessidade da revolução social" (BORON, 2001, p. 117).

Diante de distintas realidades socioeconômicas e culturais, as vertentes do marxismo abordaram diferentes aspectos da totalidade. O leninismo, no cenário russo em que foi elaborado, em uma estrutura econômica pouco desenvolvida e um proletariado incipiente, valorizou o papel do partido e das vanguardas na condução do processo revolucionário, enquanto o luxemburguismo, na Europa, com uma sociedade civil suficientemente articulada para exercer pressóes significativas sobre a estrutura estatal, privilegiou a construção de uma hegemonia revolucionária.

As divergências entre os pensamentos de Rosa Luxemburg e Lênin sobre o caráter das organizaçóes proletárias no processo revolucionário devem-se sobretudo a uma questão de princípios, não apenas de ênfase. 
Enquanto ele as aborda do ponto de vista da organização, ela as considera do ponto de vista da espontaneidade e da iniciativa de massas. Essas divergências ocorrem em função das condiçóes concretas em que se travam as lutas de classes nas distintas realidades vivenciadas por ambos. No contexto da social-democracia alemá, as tendências reformistas tanto do partido quanto dos sindicatos afastavam-nos das massas, ao passo que Lênin enfrentava a necessidade de desenvolver a capacidade de dirigente perante o proletariado ainda em consolidação.

Rosa Luxemburg promove uma renovação do marxismo, empreendendo a defesa da emancipação do indivíduo singular, o combate ao "socialismo por decretos" e à ideia da instalação do socialismo sem a conscientização e ação das massas. A idéia da emancipação subjetiva aparece em todos os seus escritos e imprime uma marca à sua teoria sobre os problemas organizativos. A revolução, em seu pensamento, não se constitui apenas em necessidade de uma determinada classe social, mas em condição de existência da humanidade.

O socialismo se tornará uma necessidade histórica não só porque o proletariado não quer mais viver nas condiçôes de vida que lhes são impostas pela classe capitalista, mas também porque, se o proletariado não cumpre seu dever de classe e não realiza o socialismo, a ruína paira sobre todos nós. (LUXEMBURG, 1970 apud NEGT, 1985, p. 15).

Os limites da produção capitalista devem ser pensados não apenas do ponto de vista do aumento da produtividade e da riqueza social, mas também na perspectiva da sobrevivência da humanidade. Em função das formas assumidas pela estrutura da produção do capitalismo contemporâneo, em que sua autorreprodução suplanta as necessidades da produção e do consumo, as preocupaçóes e desafios relacionam-se agora também à continuidade histórica da sociedade humana (MÉSZÁROS, 2002, p. 698).

O desenvolvimento do sistema capitalista avança sempre no sentido de sua continuidade e de supressão das alternativas socialistas. A superação quase que automática do modo de produção capitalista, em função de sua característica imanente de ampliação contínua e ilimitada de produção da riqueza - elemento de positividade do sistema -, é vedada pelos atuais mecanismos de autorreprodução, orientados para o consumo destrutivo e 
pelo papel do Estado na articulação das condiçóes materiais e na difusão de um senso comum favorável a essa lógica (MÉSZÁROS, 2002, p. 694).

A questão da democracia assume relevância nesse quadro de referências de alternativas socialistas em função da importância da disseminação de valores e de conhecimentos científicos voltados para a elaboraçáo do processo contra-hegemônico.

Rosa Luxemburg (1981 apud NEGT, 1985) defende a "democracia de base", uma forma político-organizativa que apresenta como fundamentos essenciais a greve de massas e os conselhos dos operários e dos soldados. A autora apresenta-se, portanto, como partidária da "democracia conselhista" e, no conjunto do pensamento materialista, elabora o problema da contingência, do acaso (NEGT, 1985). O socialismo e a barbárie colocam-se como probabilidades, uma tão proeminente quanto a outra. Os proletários, por sua vez, são considerados como indivíduos empíricos, portadores de características individuais, fruto das influências da ordem hegemônica, cujas qualidades "somente se recompóem em uma vontade capaz de ação na luta de classe" (NEGT, 1985, p. 17).

Luxemburg (1981 apud NEGT, 1985) concebe a dialética entre espontaneidade e organização como a característica essencial dos processos sociais e da dinâmica política das açóes emancipatórias da classe proletária. Para ela, a espontaneidade não consiste na dinâmica da organização das massas, mas sem esta, que representa a forma pela qual os trabalhadores "conferem expressão demonstrativa e pública a seus interesses, estas se movem sempre apenas no âmbito e no interesse da ordem do poder existente" (NEGT, 1985, p. 20). A espontaneidade à qual se refere a autora é sempre mediata, em dois sentidos: primeiro, os operários apresentam sempre um comportamento espontâneo, mesmo que contrário às tendências da organização em questão; segundo, é mediatizada por um contexto social determinado pelas contradiçôes do modo de produção capitalista em determinado estágio histórico.

No debate com Bernstein sobre as possibilidades da revolução socialista - defendida pelo partido social-democrata da década de 1920 - frente às propostas "revisionistas" de implementação de reformas graduais no modo de produção capitalista para uma ascensão gradual ao socialismo, operado de forma idealista, Rosa Luxemburg (1970) condena o abandono, operado por esta vertente do movimento operário, do objetivo final da luta proletária 
que é a superação do capitalismo e a instauração do socialismo. Para ela, a reforma socialista por meio das açóes dos sindicatos e das cooperativas, proposta por Bernstein, na verdade representa uma alteração no "modo de repartição capitalista”, pois a reforma, encarada como meio de reduzir os lucros do capitalista e aumentar a riqueza do proletariado, acaba por "renunciar à luta contra o modo de produção capitalista” (LUXEMBURG, 1970, p. 84).

o objetivo final do socialismo é o único elemento decisivo na distinção do movimento socialista da democracia burguesa e do radicalismo burguês, o único elemento que, mais do que dar ao movimento operário a tarefa inútil de substituir o regime capitalista para o salvar, trava uma luta de classe contra esse regime, para o destruir. (LUXEMBURG, 1970, p. 10).

Ancorada em Marx, a pensadora alemã frisa que o modo de repartição de uma dada estrutura socioeconômica é calcada no seu modo de produção, portanto a instalação de um modo de repartição socialista necessariamente deve suprimir o modo de produção capitalista (LUXEMBURG, 1970). Concluímos que, para ela, a reforma social e a revoluçáo são elementos conjuntos de um mesmo complexo processo de transformaçóes, cujo caráter dependerá de seu conteúdo frente à superação de uma determinada ordem social por outra.

Para a social-democracia lutar dia a dia, no interior do próprio sistema existente, pelas reformas, pela melhoria da situação dos trabalhadores, pelas instituiçóes democráticas, é o único processo de iniciar a luta da classe proletária e de se orientar para o objetivo final, quer dizer: trabalhar para conquistar o poder político e abolir o sistema salarial. Entre a reforma social e a revolução, a social-democracia vê um elo indissolúvel: a luta pela reforma social é o meio, a revolução social o fim. (LUXEMBURG, 1970, p. 9).

Os argumentos de que o socialismo científico não permite a instauraçáo de uma estrutura social democrática, a qual, por sua vez, demanda a instalação de organizaçóes sociais burocráticas, trazem à tona as seguintes questôes: a qual vertente do marxismo estamos nos referindo? Qual o período histórico e o espaço geográfico de sua elaboração, ou 
seja, sob quais condiçóes estruturais e com quais necessidades a vertente dialoga?

O debate entre autores marxistas sobre a Revolução de Outubro demonstra que houve um embate entre as posições reformistas, defensoras de uma tomada de poder que congregasse forças revolucionárias e burguesas, e as posiçóes revolucionárias, defensoras de um governo majoritariamente proletário. Entretanto, mesmo entre os que saudaram a defesa leninista de um poder eminentemente revolucionário há os que reconheceram e chamara a atenção para o caráter autoritário e burocrático do partido único que não conciliou as forças socialistas de outras tendências.

As experiências das sociedades pós-capitalistas de tipo soviético demonstraram que a "socialização" (na verdade, a transferência para o Estado) dos meios de produção não democratizou a sociedade por não ter rompido com a organização taylorista-fordista do trabalho, permanecendo eternamente no estágio transitório em direção ao socialismo.

Conclui-se, portanto, que a construção de uma sociedade socialista requer a superação não apenas do capitalismo, com a socialização dos meios de produção, mas também a aniquilação do capital como elemento de subjugação do trabalho. A transferência do capital dos proprietários individuais para o controle do aparato burocrático do partido não garante a sua supressão, uma vez que o conjunto dos trabalhadores permanece alienado de seu papel de controle da produção social e da organização da produção no local de trabalho, assim como a extração do excedente do trabalho permanece nas mesmas bases, como ação externa.

O trabalho submetido aos imperativos materiais da expansão do capital, controlado por um poder imposto sobre o processo de trabalho também sob as formas conhecidas de extração política do trabalho excedente, permanece dominado pela alienação tanto no sentido de ser dominado por um poder estranho de tomada de decisóes como pelo fato de que os frutos do trabalho excedente são dele alienados. (MÉSZÁROS, 2002, p. 747).

Numa estrutura socioeconômica socialista os objetivos da estrutura produtiva são definidos "por todos aqueles que têm que recorrer aos 
seus próprios recursos de modo a traduzi-los em realidade, avaliando a realização de seus objetivos escolhidos em base inerentemente qualitativa". (MÉSZÁROS, 2002, p. 751).

Tudo indica, portanto, que as formas organizacionais e institucionais para a criação, desenvolvimento e consolidação de uma orientação políticoideológica socialista devem romper com a lógica e formas atuais, estruturadas a partir do paradigma capitalista, assim como devem ser analisadas a partir das experiências pós-capitalistas na Rússia pós-1917.

Entre os entusiastas da tomada de poder pelos revolucionários, empreendida por Lênin, estão Luxemburg e Martov (considerado a "consciência autêntica da revolução", este condena as formas violentas de tomada do poder). Conforme Getzler (1985, p. 49-50), Martov era "líder da oposição dos mencheviques internacionalistas dentro do partido no governo provisório", contra a defesa da coalizão com a burguesia, e defensor de "um governo 'democrático' com ampla base, uma espécie de governo de frente popular [...]". Martov atuou na tentativa de impedir uma ditadura do Partido Bolchevique e, posteriormente, buscou sua democratização.

A prática efetiva de uma tal ditadura, assim como as relações que ela instituiria entre a minoria ditatorial e as massas, iriam 'educar' os ditadores, segundo Martov, para serem tudo menos pessoas capazes de 'guiar a construção da nova sociedade'; quanto às massas, uma educação deste tipo só poderia 'corrompê-las e degradá-las'. Portanto se o objetivo era uma sociedade socialista, a 'condição indispensável' deveria ser o 'máximo desenvolvimento possível da iniciativa organizada' das massas operárias, o que era absolutamente incompatível com o 'regime ditatorial de uma minoria' e suas conseqüências inevitáveis, 'o terror e a burocracia'. (GETZLER, 1985, p. 53).

Tanto em Martov quanto em Luxemburg a defesa de um governo democrático baseia-se no argumento de que este processo de organização política constitui um pré-requisito de uma sociedade socialista, uma vez que a "ditadura do proletariado" consiste em um regime de participação das massas nos processos decisórios. Para a implementaçáo de um regime participacionista 
tanto os dirigentes quanto a grande maioria devem ser educados para a democracia; esta educação consiste na vivência democrática. Em Luxemburg encontramos a defesa de que "entre os pré-requisitos do socialismo está a liberdade política", pois esta constitui um elemento essencial da "educação política e plena participação das massas, indispensável ao socialismo" (GETZLER, 1985, p. 63). O caráter democrático da estrutura organizativa das instituições do proletariado, e também do socialismo como organização sociopolítica, não representa apenas um postulado para seus objetivos finais, mas "tem também o seu fundamento metodológico" (NEGT, 1985, p. 30).

Como necessidade histórica para a construção do socialismo, Luxemburg defende o desenvolvimento da consciência de classe "como capacidade intelectual para a compreensão da estrutura da sociedade classista e das relaçóes históricas do proletariado". Este desenvolvimento da consciência de classe está subordinado à politização dos interesses cotidianos e das necessidades dos homens nos locais onde se manifestam: "na fábrica, na família, na escola, no tempo livre etc.” (NEGT, 1985, p. 29-30).

Luxemburg entende que a burocratização, concebida como disciplina imposta por uma ordem externa, não permite o rompimento da subjugação do proletário à moral burguesa imposta por suas instituiçóes. $\mathrm{O}$ autoritarismo nas relaçōes individuais e sociais deixa os indivíduos suscetíveis ao retorno a posiçôes de subserviência em relação à direita. Somente o "momento da livre e espontânea articulação das necessidades e da participação coletiva, autônoma, uma forma de autorregulamentação" pode desenvolver a consciência de classe (NEGT, 1985, p. 31). Destacamos no pensamento de Lênin, em consonância com os princípios do materialismo históricodialético, que "a questão da organização não pode ser resolvida no terreno das medidas técnico-organizativas, mas deve ser entendida como um tema político que não admite uma reflexão isolada da concreta situação social e histórica" (NEGT, 1985, p. 23).

\section{Conclusão}

A questão da democracia constitui um terreno de embate entre as diferentes vertentes do pensamento marxista, as quais, não obstante suas divergências, possuem em comum a aceitação do princípio de seu caráter de classe social, diferentemente das concepçóes que imprimem um caráter 
universal a esta forma de organização política. O interesse em identificar os contrastes entre estas diferentes abordagens deve-se às implicaçóes sobre o caráter essencialmente democrático das concepçóes acerca das relaçóes entre Estado e sociedade e, por conseguinte, nas definiçóes do papel a ser assumido pela sociedade civil e pelo Estado, no bojo das reformas políticas mais amplas, como a do aparelho do Estado, assim como, na esfera da educação, a organização dos Conselhos Municipais e Escolares de Educação.

\section{Notas}

1 A democracia é aqui analisada para além da perspectiva liberal. Esta, na tentativa de apresentar soluçóes para o dilema entre liberdade e igualdade, busca o fortalecimento das liberdades formais e do direito privado na forma do associativismo (com respaldo em Tocqueville) ou o fortalecimento da constituição e do parlamento como fórmulas políticas utilizadas pelas elites para legitimar o governo das classes dirigentes (com fundamento em Gaetano Mosca). Na verdade, os regimes liberais incorporaram direitos políticos, tais como o sufrágio universal e a liberdade de organização sindical e partidária, por pressão da mobilização das classes trabalhadoras; esses regimes, portanto, constituíram-se paulatinamente em regimes democráticos, mas o dilema original permanece, qual seja, a necessidade de controle das conquistas democráticas, incorporando-as à lógica do sistema capitalista, tendo em vista que a progressiva democratização da política colide com a apropriação privada do Estado por parte dos representantes das classes economicamente dominantes (COUTINHO, 2008).

2 O aumento da produtividade para a satisfação das necessidades humanas não se refere apenas ao aspecto quantitativo desta produção, pois sob o modo de produção capitalista vivenciamos um estágio do processo de desenvolvimento no qual a expansão quantitativa da produção orienta-se para um caráter destrutivo (MÉSZÁROS, 2002).

\section{REFERÊNCIAS}

BORON, Atílio A. A coruja de minerva: mercado contra democracia. Petrópolis: Vozes, 2001. 
CHAUÍ, Marilena. Cultura e democracia: o discurso competente e outras falas. São Paulo: Cortez, 2000.

COUTINHO, Carlos Nelson. Democracia um conceito em disputa. Rio de Janeiro, 2008. Disponível em: <http://www.socialismo.org.br/portal/ filosofia/155-artigo/699-democracia-um-conceito-em-disputa->. Acesso em: 20 mar. 2010.

ENGELS, Friedrich. Do socialismo utópico ao socialismo científico. In: MARX, Karl; ENGELS, Friedrich. Obras escolhidas. São Paulo: AlfaOmega, 1987. v. 2. p. 281-336.

FELIX, Maria de Fátima Costa. Administração escolar: um problema educativo ou empresarial. 4. ed. São Paulo: Cortez, 1989.

GETZLER, Israel. Outubro de 1917: o debate marxista sobre a revolução na Rússia. In: HOBSBAWM, Eric J. (Org.). História do marxismo. Tradução Carlos Nelson Coutinho; Luiz Sérgio N. Henriques. Rio de janeiro: Paz e Terra, 1985. v. 5. p. 35-69.

GONÇALVES, Maria Dativa S. Dimensóes críticas no estudo da especificidade da administração educacional. 1980. Dissertação (Mestrado em Educação) - Universidade Federal do Paraná, Curitiba, 1980.

HOBSBAWM, Eric J. História do marxismo. Tradução Carlos Nelson Coutinho; Luiz Sérgio N. Henriques. Rio de janeiro: Paz e Terra, 1985. v. 5.

LENINE, V. I. O estado e a revoluçâo: a doutrina do marxismo sobre o Estado e as tarefas do proletariado na revolução. Lisboa: Progresso, 1978. LUXEMBURG, Rosa. Reforma ou revolução? 4. ed. Tradução Manuel Augusto Araújo. Lisboa: Estampa, 1970.

MÉSZÁROS, István. Para além do capital: rumo a uma teoria da transição. Tradução Paulo César Castanheira; Sérgio Lessa. São Paulo: Boitempo, 2002.

NEGT, Oscar. Rosa Luxemburgo e a renovação do marxismo. In: HOBSBAWM, Eric J. (Org.). História do marxismo. Tradução Carlos Nelson Coutinho; Luiz Sérgio N. Henriques. Rio de Janeiro: Paz e Terra, 1985. v. 3. p. 15-39.

PARO, Victor Henrique. Administração escolar: introdução crítica. São Paulo: Cortez, 2000. 


\section{Democracy to overcome capital in marxist thought: subsidies for reflections about educational organization}

\begin{abstract}
This article presents bibliographic research motivated by debates about participation in decision making processes in the context of political and educational reforms in the 1990s. It affirms that democracy is the basic premise for social change, according to Marxist authors. The study presents Marx and Engels's analysis of the historic development of collective production planning and the necessary maintenance of productivity levels required to create conditions to overcome capitalism. It presents Luxemburg and Lenin's disagreements about the transition to socialism and Luxemburg's defense of mass participation in decision making. It concludes that the approach to political factors of organizational issues, concomitant to guaranteed access to historically produced knowledge, require advances in the analysis of the organizational principles of education based on the specificities of this social practice.
\end{abstract}

Keywords: Democracy. Educational management. Marxism. Education.
La democracia para superación del capital en el pensamiento marxista: subsidios para reflexiones sobre la organización educativa

\section{Resumen}

Se presenta un artículo de investigación bibliográfica, motivado por los debates en torno al tema de la participación en el proceso de decisiones en un contexto de reformas políticas y educativas del año 1990. Apoyamos la tesis donde la democracia constituye una premisa básica para la transformación social en el pensamiento de los autores marxistas. Se presenta: en Marx y Engels, el análisis del desarrollo histórico de un proceso de planificación de la producción colectiva y el mantenimiento de los niveles requeridos de la productividad como condición previa para crear las superaciones del capitalismo; en Luxemburgo y Lênin, las divergencias en el proceso transitorio del socialismo; en Luxemburgo, la defensa de la participación masiva en la toma de decisiones. Creemos que el enfoque de los aspectos políticos en cuestiones de organización, concomitante con la garantía de acceso a los conocimientos generados históricamente, se requieren avances en el análisis de los principios de organización de la educación y en las particularidades de esta práctica social. Palabras clave: Democracia. Gestión educativa. El marxismo. La educación. 


\section{Angela Maria Hidalgo}

E-mail: angelamhidalgo@yahoo.com.br

Recebido em: 7/6/2010

Versão final recebida em: 15/3/2011

Aprovado em: 20/4/2011 